\title{
Specific features of the concept «Family» in the advertising and public service announcements discourse
}

\section{[Специфика концепта семья в рекламном дискурсе]}

\author{
Marina V. Terskikh
}

\section{DOI: 10.18355/XL.10.04.10}

\begin{abstract}
Аннотация
Статья посвящена влиянию рекламы на формирование ценностных установок современного общества. Средства массовой информации, в том числе рекламные сообщения, в настоящее время можно рассматривать как мощнейший инструмент создания моральных ориентиров общества в целом и подрастающего поколения в частности. В качестве примера автор моделирует один из значимых элементов национальной концептосферы - концепт семьи, формируемый и транслируемый посредством текстов коммерческой и социальной рекламы.
\end{abstract}

Ключевые слова: концепт, концептосфера, семья, реклама, социальная реклама, социальные ценности

\section{Введение}

Концепт семья относится к ключевым концептам русской культуры, его изучению посвящены труды многих ученых: 3.А. Биктагировой (Biktarigova, 2007), М.В. Матвеевой (Mateeva, 2007), М.А. Терпак (Terpak, 2006), Е.В. Добровольской (Dobrovskaya, 2005), А.С. Сказко (Skazko, 2005) и др. Исследование концепта семья осуществлялось на материале произведений художественной литературы (Kireeva, 2008; Chistyakova, 2004), текстов семейных родословных (Ruhlenko, 2005), однако функционирование данного концепта в текстах рекламной сферы до сих пор оставалось за пределами внимания исследователей. Между тем исследование концепта семья именно в рекламных текстах представляется нам особенно важным в связи с той возросшей ролью, которую играет реклама - как коммерческая, так и социальная - в современном обществе. Эта роль заключается не только в стимулировании сбыта товаров и услуг, информировании общественности о ключевых социальных проблемах, но и в трансляции и формировании социальных норм, ценностей, стереотипов.

Изучение роли текстов массовой коммуникации как инструмента формирования стереотипных представлений в настоящее время находится в центре внимания лингвистов-когнитологов (Marcin, 2011; Rozenfeld, 2011; Осипова, Михина, Позднякова, 2016; Шулежкова, Михин, Чернова, 2016 и др.). Реклама при этом предстает как дискурс влияния: с одной стороны, реклама отражает уже сложившиеся традиции, нравственные устои и ценности нашего общества; с другой стороны, своей убедительностью и силой эмоционального воздействия рекламные тексты вносят существенные изменения в систему ценностей, стиль жизни современного человека, влияют на формирование его убеждений и идеалов.

Таким образом, в фокусе нашего внимания - влияние рекламы на отдельные институты общества, в частности на институт семьи. Положение семьи, уровень ее стабильности во многом определяют жизнестойкость и благополучие нации и общества в целом. Реклама может оказывать как негативное, так и благоприятное влияние на жизнедеятельность семьи. Пропагандируя определенные модели поведения и взаимоотношений в семье, сообщения коммерческой и социальной рекламы способны внести существенные 
изменения в вековые семейные устои, корни которых лежат в крестьянской семье: привязанность к своей группе, к своей общине, почитание старших. В то же время реклама является тем институтом, который способен в той или иной степени возродить эти устои и сохранить семью как социальный институт.

Цель данного исследования заключается в том, чтобы сопоставить существующий в сознании носителей языка концепт семья с его реализацией в текстах коммерческой и социальной рекламы.

Исследование было проведено на материале российской социальной рекламы преимущественно наружной и печатной - 105 текстов. При проведении сопоставительного анализа материалом для исследования послужили лексикографические источники (около 10 словарей различного типа), тексты русских пословиц и поговорок, результаты ассоциативного и рецептивного экспериментов, тексты коммерческой рекламы. Для моделирования концепта семья в дискурсе коммерческой рекламы мы проанализировали 50 рекламных роликов и 15 печатных рекламных текстов. Акцент делался на телевизионной рекламе, т.к. именно этот вид рекламы оказывает, на наш взгляд, наиболее сильное воздействие на адресата в связи с широким охватом аудитории, сочетанием вербального текста и видеоряда.

При проведении исследования мы отталкивались от следующей гипотезы: концепт семья, моделируемый на основании текстов социальной рекламы отличается от концепта семья, существующего в сознании носителей русского языка и представленного в сообщениях коммерческой рекламы. При этом трансформация данного концепта и в коммерческой, и в социальной рекламе осуществляется осознанно.

\section{Методика}

Для решения поставленных задач в исследовании применяется комплексная методика, включающая метод контент-анализа, метод анализа словарных дефиниций, методы концептуального, семного и сравнительносопоставительного анализа. Метод анализа словарных дефиниций позволяет выделить доминантные признаки общеязыкового концепта. Метод концептуального анализа применяется при реконструировании концепта, выявлении его структуры. Семный анализ позволяет осуществить компонентный анализ содержания концепта. Метод контент-анализа используется при моделировании полевой структуры концепта и концептосферы для определения ядерного, приядерного и периферийного слоев. Сравнительно-сопоставительный анализ направлен на определение специфики концептов в конкретной сфере - дискурсе социальной рекламы - в соотношении с языковой реализацией того или иного концепта.

Подчеркнем, что концепт - это не только языковое явление. В первую очередь это невербальное, а затем уже вербальное воспроизведение действительности. Поэтому при описании концепта семья в рекламных текстах следует обращать внимание не только на всю совокупность его языковых репрезентантов, но и на невербальные компоненты. Это положение будет для нас особенно важным при анализе наружной и телевизионной рекламы, где большая часть информации подается именно на невербальном уровне. Невербальный компонент рекламного сообщения может иметь собственное семантическое значение и принимать участие в создании образного ряда, привносить в сообщение дополнительные смыслы и ценности. Так, само слово «семья» и другие слова-репрезентанты этого концепта могут и не употребляться в рекламном сообщении, и концепт семья может быть представлен только образом конкретной семьи, который возникает на фоне основного рекламного текста.

XLinguae, Volume 10, Issue 4, October 2017, ISSN 1337-8384, eISSN 2453-711X 


\section{Концепт семья в русской языковой картине мира}

Для того чтобы представить специфику концепта семья в дискурсе коммерческой и социальной рекламы, рассмотрим структуру данного концепта в русской языковой картине мира.

Высокая частотность и разнообразие лексической объективации концепта семья свидетельствует о том, что данный концепт представляет собой одно из ключевых понятий культуры, опорных точек национального менталитета.

Как подтверждает проанализированный материал, слово «семья» связано у россиян с понятием глубокой нравственности, социальной стабильности и покоя. Это представление о семье как о носителе таких базовых ценностей, как любовь, забота, долг, ответственность, глубоко заложено в менталитете носителей русского языка.

Ключевая лексема, представляющая данный концепт в русском языке, «семья». Концепт вербализуется также производными словообразовательными единицами: «семейный», «семейственный», «семьянин» $и д р$, а также рядом синонимов: «семейство», «дом», «домашний очаг».

На основании словарных дефиниций можно выявить следующие ядерные компоненты концепта семья: члены семьи (муж, жена, дети и др.); родство; совместное проживание.

Для получения более полного представления о концепте семья мы проанализировали определения производных словообразовательных единиц ключевого слова, данные в «Толковом словаре русского языка» С.И. Ожегова и Н.Ю. Шведовой (Ожегов, Шведова, 1995):

\section{СЕМЕЙНЫЙ}

1. Имеющий семью

2. Предназначенный для семьи, семей

3. То же, что семейственный (во 2 знач.)

В «Словообразовательном словаре русского языка» А.Н. Тихонова (Тихонов, 1985) зафиксировано дополнительное значение прилагательного СЕМЕЙНЫЙ: неодинокий.

\section{СЕМЕЙСТВЕННЫЙ}

1. Приверженный к семье, к семейной жизни

2. Основанный на предоставлении льгот родственникам, устройстве на работу под своим начальством (неодобр.)

СЕМЬЯНИН

1. Человек, обладающий качествами, необходимыми для семейной жизни

2. Человек, имеющий семью, а также глава семьи (устар.).

Таким образом, анализ деривационных возможностей ключевого слова показал: для того, чтобы создать семью, жить в семье, необходимо от природы обладать определенными качествами: скорее всего, быть основательным, надежным.

Лексическая сочетаемость ключевого слова, выявленная на основании данных «Учебного словаря сочетаемости слов русского языка» под ред. П.Н. Денисова, В.В. Морковкина (Учебный словарь сочетаемости слов русского языка, 1978]) позволяет выявить такие дополнительные компоненты в концепте семья, как размер семьи (большая, маленькая), материальное положение (богатая, бедная, обеспеченная), общественная оценка (хорошая, плохая, образиовая), связь с профессией (интеллигентная, рабочая, семья учителя, колхозника и т.д.), ценность, значимость для человека (жить для семьи, заботиться о семье, любить семью, беспокоиться о семье, скучать, тосковать по семье).

Метафорические сочетания семейные yзы, построить, разрушить 
семью, семейная жизнь, семейный уклад, в которых семья выступает как неделимый субъект, позволяют выявить такие компоненты, как целостность, крепость, единство семьи.

Для описания интерпретационного поля концепта семья мы использовали пословицы, поговорки и крылатые выражения русского языка, объективирующие данный концепт. Анализ таких паремий, как «Чувство семьи единой», «Вся семья вместе, так и душа на месте» и др. позволил выявить дополнительные признаки исследуемого концепта: чувства, объединяющие членов семьи, их кровная привязанность друг к другу. В русских пословицах и поговорках нашли отражение также следующие представления и установки, связанные с семьей: в своей семье каждый человек чувствует себя уверенным и защищенным: «В своей семье всяк сам большой», "И в Польше нет хозяина больше»; семья - это самое ценное и дорогое в жизни каждого человека: «Родной куст и зайиу дорог», "В родном углу все по нутру», "Где птииа не летает, а свое гнездо знает», в счастливой семье царит мир и согласие: "Нa что и клад, коли в семье лад», «Где любовь и совет, там и горя нет», «Тишь да гладь, да Божья благодать».

Помимо положительных установок, связанных с семьей, русские пословицы и поговорки отражают существующие в русском сознании представления о проблемах, ссорах, трудностях в семье: «В семье не без урода», "Кому от чужих, а нам от своих», "Ссора в своей семье до первого взгляда».

Для выявления конституирующих признаков концепта семья, значимых для современных носителей русского языка, мы провели рецептивный и свободный ассоциативный эксперименты. Респондентам предлагалось дать собственное определение понятию СЕМЬЯ и назвать ассоциации, которые вызывает у них слово-стимул СЕМЬЯ. В опросе приняло участие 50 человек: мужчины и женщины в возрасте от 18 до 50 лет различного рода занятий (студенты, рабочие, служащие).

Результаты исследования представлены в таблице 1:

Таблица 1

\begin{tabular}{|c|c|c|c|}
\hline СЕМЬЯ - ЭТО... & $\begin{array}{l}\text { Кол-во } \\
\text { ответов }\end{array}$ & $\begin{array}{l}\text { Реакции на слово- } \\
\text { стимул СЕМЬЯ }\end{array}$ & $\begin{array}{l}\text { Кол-во } \\
\text { ответов }\end{array}$ \\
\hline Дом (домашний очаг) & 2 & Дом (домашний очаг) & 13 \\
\hline $\begin{array}{l}\text { Ячейка общества (малая } \\
\text { социальная группа) }\end{array}$ & 14 & Ячейка общества & 2 \\
\hline $\begin{array}{l}\text { Тепло (поддержка } \\
\text { взаимопонимание) }\end{array}$ & 4 & $\begin{array}{l}\text { Тепло (поддержка } \\
\text { гармония) }\end{array}$ & 7 \\
\hline $\begin{array}{l}\text { Любовь (любящие друг } \\
\text { друга люди... / союз двух } \\
\text { любящих друг друга } \\
\text { людей...) }\end{array}$ & 5 & $\begin{array}{l}\text { Любовь } \\
\text { любят) }\end{array}$ & 8 \\
\hline $\begin{array}{l}\text { Гнездо родственников } \\
\text { (родные люди / малая } \\
\text { соц. группа, включающая } \\
\text { родственников, союз } \\
\text { родственных друг другу } \\
\text { людей, связь на основе } \\
\text { родства) }\end{array}$ & 5 & Родная (родня) & 4 \\
\hline $\begin{array}{l}\text { Счастье (счастливая } \\
\text { ячейка общества) }\end{array}$ & 6 & Счастье (радость) & 2 \\
\hline Дети (родители) & 3 & $\begin{array}{ll}\text { Дети } & \text { (родители } \\
\text { мама) } & \end{array}$ & 7 \\
\hline
\end{tabular}

XLinguae, Volume 10, Issue 4, October 2017, ISSN 1337-8384, eISSN 2453-711X 


\begin{tabular}{|c|c|c|c|}
\hline Мама, папа, я & 2 & Муж, жена, дети & 2 \\
\hline $\begin{array}{llr}\text { Духовный } & \text { союз } & \text { (союз } \\
\text { двух любящих друг } & \text { друга } \\
\text { людей... } & / & \text { союз } \\
\text { родственных } & \text { друг } & \text { другу } \\
\text { людей }) & & \\
\end{array}$ & 3 & Союз & 1 \\
\hline Корень человека & 1 & $\begin{array}{l}\text { Опора, } \\
\text { поддержка }\end{array}$ & 3 \\
\hline $\begin{array}{l}\text { Группа людей, связанных } \\
\text { брачными узами (союз } \\
\text { двух любящих друг друга } \\
\text { людей, вступающих в } \\
\text { брак) }\end{array}$ & 2 & Свадьба & 1 \\
\hline Моя семья & 1 & Мы все & 1 \\
\hline $\begin{array}{l}\text { Любящие друг друга } \\
\text { люди, живущие вместе }\end{array}$ & 1 & Все вместе & 1 \\
\hline Доверие & 1 & Доверие & 1 \\
\hline $\begin{array}{l}\text { Люди, объединенные } \\
\text { общением и добрым } \\
\text { отношением } \begin{array}{cr}\text { друг } \\
\text { другу }\end{array}{ }^{2}\end{array}$ & 1 & Мир & 1 \\
\hline $\begin{array}{l}\text { Группа людей, имеющих } \\
\text { кровную связь } \\
\text { духовное единство }\end{array}$ & 1 & Родная кровь & 1 \\
\hline $\begin{array}{l}\text { Главное в жизни, ради } \\
\text { чего стоит жить (главное } \\
\text { / самое главное) }\end{array}$ & 5 & Уют & 5 \\
\hline $\begin{array}{l}\text { Гармония между людьми, } \\
\text { имеющими } \\
\text { жизненные ценности }\end{array}$ & 1 & $\begin{array}{l}\text { Стабильность } \\
\text { (надежность, } \\
\text { надежная) }\end{array}$ & 5 \\
\hline Надолго & 1 & $\begin{array}{ll}\text { Большая } \\
\text { человек) }\end{array}$ & 2 \\
\hline Правильно & 1 & Вечер (выходные) & 2 \\
\hline Институт & 1 & Ужин & 1 \\
\hline $\begin{array}{l}\text { Любят, ценят, уважают } \\
\text { традиции }\end{array}$ & 1 & Собака & 1 \\
\hline & & Древо & 1 \\
\hline & & Гнездо & 1 \\
\hline & & Крепкая & 1 \\
\hline & & Дружба & 1 \\
\hline & & Доброта & 1 \\
\hline
\end{tabular}

Таким образом, анализ реакций на слово-стимул СЕМЬЯ, а также субъективных дефиниций данного понятия показал, что для современных носителей русского языка наиболее значимыми являются следующие семантические компоненты исследуемого концепта: дом, ячейка общества, родство, счастье, гармония, взаимопонимание, поддержка, главное в жизни, уют, стабильность.

\section{Фреймовая модель концепта семья.}

Проанализировав схему фреймовой модели английского концепта семья, которую предлагает М.А. Терпак (Терпак 2006: 9-19), построим фреймовую модель русского концепта семья и рассмотрим содержание основных слотов и подслотов данного фрейма, используя пословицы, поговорки и 
фразеологизмы русского языка, а также результаты ассоциативного эксперимента. При этом некоторые результаты наших наблюдений и исследований мы будем соотносить с данными, полученными М.А. Терпак при анализе концептуализации английской семьи.

\section{Терминал 1. Нуклеарная семья}

В данном терминале семья представляется как двое родителей и их дети, живущие под одной крышей.

\section{Слот 1. Родители и дети}

В отличие от английской семьи, где, по результатам исследования М.А. Терпак, в отношениях между родителями и детьми господствует «независимость и холодность, граничащая с отчужденностью», в русской семье дети и их родители чувствуют взаимную привязанность и ответственность друг перед другом: «Родители берегут дочь до венца, а муж жену - до конца». И если в Англии родителям довольно часто приходится доживать свой век в одиночестве, то в России принято заботиться о своих родителях на протяжении всей жизни: «Не оставляй отиа и матери до старости лет, и Бог тебя не оставит». То же касается и отношения родителей к их детям: «Tот не умирает, кто детей не покидает».

Результаты ассоциативного эксперимента показали, что для современных носителей русского языка наиболее значимыми компонентами концепта родители являются забота (11 чел.), помощь (совет) (6 чел.), любовь (5 чел.), воспитание (5 чел.), ответственность (5 чел.), уважение (4 чел.).

В русской языковой картине мира концепт дети содержит в себе, помимо положительных компонентов, такие компоненты, как хлопоты («У кого детки, у того и бедки», «С мальми детьми горе, с большими - вдвое»), наказание («Не наказанный сын - бесчестие отиу»), проблемы, связанные с воспитанием («Уродился ни в мать, ни в отияа, в проезжего молодиа»). Это подтверждают и результаты ассоциативного эксперимента: респондентами, помимо таких реакций, как счастье (19 чел.), любовь (4 чел.), забота (4 чел.), цветы жизни (7 чел.), были названы хлопоты, проблемы, головная боль, болезни (7 чел.), проказничают, балуны, непоседы (5 чел.) и др.

\section{Подслот 1. Мать / отец}

В сознании русского человека мать - это не только источник жизни и всего жизненно необходимого для детей, но и источник сил, энергии, добра, заботы, нежности: «При солние тепло, при матери добро», «Птица радуется весне, младенеи матери». Материнство предполагает любовь и полную самоотдачу: «Материнское сердие в детках». На протяжении всей жизни мать является для ребенка самым родным и близким человеком: «Нет такого дружка, как родная матушка».

В концепте отеи также присутствуют такие компоненты, как любовь, забота: «Как Бог до людей, так отеи до детей». Однако отношения с отцом характеризуются большей холодностью, отчужденностью, чем отношения с матерью: «Отиов много, а мать одна» (т.е. отца легче заменить, чем мать).

В сознании ребенка отец - это прежде всего защитник («Держаться, как за родного отца»), он же является «добытчиком» (именно поэтому в их отношениях с детьми часто присутствует элемент корысти: «Плачет сын по отиу, что мало денег оставил»).

\section{Подслот 2. Сын / дочь}

Тексты русских пословиц демонстрируют трепетное отношение родителей к их детям: «жить у отцุа-матери за пазушкой». Однако считается, что чрезмерная опека и забота вредят ребенку. Именно поэтому выражения «маменькин сынок» / «папенькина дочка» имеют в русском языке явную отрицательную коннотацию.

XLinguae, Volume 10, Issue 4, October 2017, ISSN 1337-8384, eISSN 2453-711X 


\section{Подслот 3. Брат / сестра}

Основу коннотативного содержания этого подслота составляют единение и взаимопомощь. Отношения между родными братьями и сестрами в русской семье необычайно близки - не внешне, но внутренне, духовно (отсюда и выражения: «живут как брат с сестрой», «братская любовь» и др.). Однако тексты русских писателей и русские пословицы свидетельствуют и о возможности враждебности этих отношений: «Брат на брата - пуще супостата», «Хорош брат - сестру продал, хороша и сестра - от брата ушла».

\section{Терминал 2. Патриархальная семья}

Специфика человеческих отношений в патриархальной семье заключается в отсутствии постоянного общения, непосредственного участие в личных делах друг друга, но в присутствии той родственной связи и духовной близости, которая характерна для нуклеарной семьи. Здесь важно отметить также и то, что, по наблюдению М.А. Терпак, «в русском языке независимо от степени родства (родные, двоюродные, троюродные) братья и сестры называются братьями и сестрами, т.е. во всех степенях употребляется одна и та же пара слов (в отличие от английского языка, где резкое разграничение первой и второй степеней родства подчеркнуто разницей в их лексическом обозначении: brother / sister, cousin, second cousin)» (Терпак, 2006: 14).

\section{Слот 1. Дом}

Семья практически полностью ассоциируется у россиян с понятием «дом». Дом представляет собой «свое», безопасное пространство, он является воплощением идеи защиты, спокойствия и уверенности.

Это место характеризуются в сознании россиян определенной замкнутостью (хотя и не так глубоко скрыто от посторонних глаз, как жилище англичанин). Дом - это то пространство, находясь в котором каждый его обитатель может чувствовать себя хозяином. «На своей печи - сам себе голова», «Твой дом - твоя и воля». В русской культуре не принято обсуждать какие-то частные проблемы за пределами собственного дома («выносить сор из избыл»).

С домом связано ощущение тепла, уюта, чего-то близкого и родного. Но создание домашнего уюта требует определенных усилий: «Дом вести - не лапти плести». Как правило, в русской семье создание уюта и поддержание домашнего очага - обязанность женщины - хозяйки дома («Коли изба крива хозяйка плоха»).

Наиболее частотные реакции на слово-стимул ДОМ (выявленные на основании ассоциативного эксперимента): уют (13 чел), крепость (13 чел), тепло (9 чел), семья (6 чел), спокойствие (5 чел).

\section{Слот 2. Отдаленное родство}

В русском обществе с изменением степени родства связь между членами патриархальной семьи значительно ослабляется: если отношения между бабушкой/дедушкой и внуком/внучкой можно описать как очень близкие, теплые, то отношения между троюродными братьями/сестрами - как достаточно отчужденные, почти официальные. Это подтверждают результаты ассоциативного эксперимента: наиболее частотные ассоциации со словосочетанием дальние родственники: незнакомые, не знаю (6 чел), чужие (4 чел), редко видимся (4 чел), знакомые (3 чел).

Для характеристики такого дальнего, сомнительного родства в русском языке существует выражение «седьмая / десятая вода на киселе».

Собранный текстовый материал свидетельствует о том, что отношения в русской семье между дальними родственниками поддерживаются, скорее, ради взаимопомощи, чем в силу кровной привязанности. Распространенным является мнение, что дальние родственники приходят только по необходимости, всегда неожиданно и всегда не вовремя, «как снег на голову»: «Родня середь дня (т.е. в обед), а как солние зайдет - ее и черт не найдет». 


\section{Подслот 1. Двоюродные братья и сестры}

В русской семье двоюродные братья и сестры общаются довольно тесно. Отношения же между троюродными братьями и сестрами относятся, скорее, к категории дальнего родства.

\section{Подслот 2. Племянник / племянница}

Эта степень родства, по мнению М.А. Терпак (Терпак, 2006: 15), воспринимается русскими как очень близкая (в языке неслучайно существуют ласкательные просторечия - «племяш» / «племящка»).

\section{Подслот 3. Дяди / тети}

Концепт дядя или тетя в русском языке, по наблюдению М.А. Терпак, «может обозначать как степень родства, так и отсутствие родственной связи, выступая в качестве обращения ребенка к незнакомому взрослому человеку» (Терпак, 2006: 16). Соответственно, отношение к дяде/тете в русской семье можно охарактеризовать как более официальные, довольно отчужденные. Подтверждение тому - отсутствие в русском языке уменьшительно-ласкательных форм слов «дядя» и «тетя» (слова «дяденька» / «тетенька» могут употребляться только по отношению к незнакомому человеку, а слово «тетушка» относится к числу устаревших).

\section{Подслот 4. Свекровь / свекор / теща / тесть}

Собранный текстовый материал в рамках данного подслота позволяет сделать вывод о том, что в русской семье отношения к свекрови/теще, скорее, враждебные: «Свекор - гроза, а свекровь выест глаза»; «Не жалей тещина добра - колупай масло шилом». Об этом свидетельствует и то, что теща и свекровь стали постоянными персонажами русских анекдотов («Хоронили тещу порвали три баяна»).

\section{Подслот 5. Зять / сноха / невестка}

Отношение к зятю в русской семье может быть как враждебным («Нет черт в доме - прими зятя»), так и теплым, дружеским, причем, как свидетельствует собранный текстовый материал, второй вариант отношений встречается чаще. В русском менталитете есть представление о том, что теща должна заботиться о зяте, ничего не жалеть для него. Эту мысль подтверждает и существующая в русском языке ласкательная форма «зятек», и русские поговорки: «Зятек на двор - пирог на стол», «Для зятя и дверь настежь» и др.

Что же касается невестки/снохи, отношение к ней со стороны свекрови чаще всего враждебное. В русском менталитете есть ясное представление о том, как свекровь издевается над снохой («Невестушка, полно молоть! Отдохни, потолки!), считает ее глупой и неопытной («Села невестка прясть: берегите, люди, глаз»). Теплые, дружеские чувства по отношению к невестке - скорее исключение.

\section{Подслот 5. Бабушка / дедуика}

В русской семье бабушка очень часто воспитывает ребенка наравне с матерью, именно поэтому эта степень родства воспринимается русскими как очень близкая. В сознании русского человека бабушка - хранительница домашнего очага; она готовит обед, читает сказки, рассказывает истории - eе тепла и любви хватает на всех: «Бабушке один только дед не внук».

\section{Подслот 6. Внук / внучка}

В русском менталитете является довольно распространенным мнение о том, что внуки - это «вторые дети». Существование в русском языке ласкательных форм «внучек» / «внученька» подтверждает мысль о том, что эта степень родства также воспринимается русскими как очень близкая.

\section{Терминал 3. Родство по супружеству}

\section{Слот 1. Муж / жена}

В русском менталитете существует четкое разграничение понятий

XLinguae, Volume 10, Issue 4, October 2017, ISSN 1337-8384, eISSN 2453-711X 
«добрая жена» и «злая жена». Добрая жена - друг, помощник, советница: « $C$ доброй женой горе - полгоря, радость - вдвойне», с доброй женой «живут душа в душу». Злая жена - почти враг, «злая жена - та же змея».

Анализируя внутрисемейные отношения в рамках данного слота, отметим, что отношения между мужем и женой в русской семье отличаются гораздо меньшей сдержанностью и уравновешенностью, чем это принято, например, у англичан. Ссоры, раздоры и даже драки между супругами считаются обычным явлением в русской культуре. «Любить жену - держать грозу», "Раньше бывало - мужья жен бивали, а ныне живет, что жена мужа бъет». Но, несмотря на это считается, что муж и жена - всегда заодно: «Муж $и$ жена - одна сатана», «Жена да муж - змея да уж». В русском языке недаром существует выражение «вторая половинка», означающее, что муж и жена, найдя друг друга, становятся чем-то целым, единым: «Муж - голова, жена - душа», «промеж мужа и жены и нитки не проденешь».

С другой стороны, в русском языке существует выражение «брак по расчету», которое свидетельствует о возможности других, более официальных и сдержанных, отношений между супругами, основанных на корысти. В такой семье муж и жена редко вмешиваются в дела друг друга, а поиск собственной выгоды и взаимные обязательства - единственное, на чем держатся их отношения: «Будь жена хоть коза, лишь бы золотые рога», однако в русском менталитете есть также и понимание того, что такие семьи редко бывают счастливыми: «Пропади то серебро, когда жить нехорошо».

Стоит, однако, отметить, что, несмотря на возможность существования таких отношений, доминирующими компонентами концепта супруги в сознании современных носителей русского языка по-прежнему остаются любовь (16 чел.), близость (5 чел.), забота (4 чел.), доверие (3 чел.), счастье (3 чел.).

\section{Слот 2. Брак}

Содержание концепта брак существенно изменилось в современной России. Брак - это не только «союз любящих сердец», спасение от одиночества, но и, возможно, просто выгодная сделка либо осознанная необходимость: «Браки бывают по любви, по расчёту и по глупости» (Л.С. Сухоруков). Отношение к браку в корне поменялось: молодые люди, создав семью однажды, не боятся ее разрушить: «Если браки заключаются на небесах, значит, и разводы оформляются там же» (Д. Рудый).

\section{Слот 3. Измена}

Тексты русских пословиц свидетельствуют о том, что проблема измен в русской семье существовала испокон веков: «Муж того не знает, что жена гуляет», «Муж по дрова, жена со двора». Отношение к измене в русском обществе всегда было отрицательным, независимо от причины; однако последнее время взгляд на эту проблему поменялся: измены стали более привычным явлением.

\section{Слот 4. Развод}

В русском языке существует ряд слов и выражений, которые характеризуют развод: «неполная семья», «мать-одиночка», «отчим» и др. Все они имеют явную отрицательную коннотацию.

Русскими людьми потеря «второй половинки» чаще всего воспринимается как трагедия: «Жена без мужа - всегда сирота», «Видал ли ты беду? Терял ли ты жену?». Поэтому в России развод всегда считался чем-то противоестественным, противоречащим человеческой природе. Нельзя сказать, что в современном обществе концепт развод полностью потерял эту отрицательную коннотацию, хотя, несомненно, отношение к этому явлению стало более терпимым.

Итак, мы проанализировали концепт семья, существующий в сознании носителей языка. Анализ словарных статей, пословиц, поговорок, а также 
результатов ассоциативного эксперимента показал, что как для семьи в целом, так и для отдельных элементов фрейм-структуры характерна в целом позитивная эмоциональная оценка. Концепт семья обладает широким спектром положительных смыслов, коннотаций, чем и объясняется эффективность его использования в рекламных и $\mathrm{PR}$-текстах.

Далее реконструируем концепт семья на основе рекламных сообщений.

\section{Основные составляющие концепта семья в рекламной коммуникации.}

Как показывает эмпирический материал, ядро концепта семья, моделируемого на основе рекламных сообщений, составляют такие базовые компоненты, как любовь: «Моя семья - что может быть любимей», “"Простоквашино” на столе - любовь в семье»; крепость: «Кальцемин: крепкие кости - крепкая семья", "Индийский чай принцесса Нурри: крепкий чай - крепкая семья», близость: «Mы стремимся быть как можно ближе к тем, кого действительно любим. «Mы - это новый семейный тариф от МТС»).

Анализ рекламных текстов показал, что рекламный концепт семья соотносится также со следующими концептами:

- $\quad$ Еда, ужин (6 контекстов): «И все бы ничего, но только вот тот самый вкус моих любимых домашних пельменей, которые готовили у нас в семье, мне обнаружить никак не удавалось».

- Совместный отдых (6 контекстов): «Надеемся, что в будущем году удастся чащуе отдыхать всей семьей на природе в Красноярке и съездить за грибами».

- Забота (3 контекста): «К тому же, как отиу двоих детей, мне важно, чтобь моей семье бьло в автомобиле удобно».

- Традиции (2 контекста): «Комплекс «Мир подарков», расположенный в ТЦ «Омский», предлагает создать свои традииии в вашей семье».

- Здоровье (2 контекста): «B качестве готовки и здоровье семьи вы можете быть уверень на все сто!»

- Покупки (2 контекста): «Очень часто мы всей семьей приходим за покупками в Каскад».

- Воспоминания (1 контекст): «Семейнье воспоминания бесценньл. Ecть вещии, которые нельзя купить. Для всего остального есть Master Card.

Таким образом, в рекламном концепте семья отсутствуют некоторые концептуальные признаки, существующие в сознании носителей языка: размер семьи, материальное положение, проблемы, трудности и др. Преобладание положительных концептуальных признаков, таких как любовь, крепость, близость, традиции, говорит о том, что семья в рекламных сообщениях предстает в идеализированном, приукрашенном виде. Скорее всего, это связано с особенностями рекламного текста: с его прагматической направленностью, манипулятивным характером, ориентацией не столько на рациональное, критическое осмысление, сколько на эмоциональное восприятие.

Апелляция к положительным компонентам концепта семья позволяет не только вызвать у адресата светлые, теплые чувства, ассоциации, но и расширить смысл рекламного сообщения. Образ «идеальной» семьи, эксплуатируемый в рекламе, косвенно указывает на то, что фирма не просто предлагает качественный продукт, но и дает возможность с помощью данного продукта, без особых усилий, добиться той же гармонии и взаимопонимания в семье.

\section{Анализ фреймовой модели рекламного концепта семья:}

Терминал 1. Нуклеарная семья

Образ полной нуклеарной семьи представлен в 23 рекламных текстах. В

XLinguae, Volume 10, Issue 4, October 2017, ISSN 1337-8384, eISSN 2453-711X 
некоторых текстах есть упоминание лишь об одном из родителей, однако нет оснований полагать, что второй родитель отсутствует вообще: в 11 рекламных текстах используется только образ мамы, а в 5 - только образ папы.

Слот 1. Родители - дети (актуализируется в 38 рекламных текстах)

Реклама демонстрирует исключительно мирные, дружеские отношения между детьми и родителями. В рекламном слоте «родители - дети» полностью отсутствуют такие компоненты, как ссора, наказание и т.д. Хлопоты, связанные с воспитанием детей, могут быть только приятными. Детские шалости не являются причиной раздражения, гнева родителей, а могут вызвать у них лишь улыбку.

Подслот 1. Мать / отец (концепт мать представлен в 23 рекламных текстах, а концепт отеи - в 15 рекламных текстах).

В рекламе актуализируются следующие компоненты концепта мать:

- любовь, самоотдача: «Быть матерью - значит дарить много любви...» (из рекламного ролика Киндер-шоколада);

- внимание, забота: «Здравствуй, дорогая мама... Спасибо тебе огромное от меня и от всей роты за посылку с «Нъю Милки Экстра...»;

- нежность, добро. Чаще всего это выражается на невербальном уровне: мама ласково целует, обнимает ребенка (реклама творожка Растишка), бережно укладывает его спать (реклама масла Johnson's Baby), старается утешить его в трудную минуту (реклама витаминов Йодомарин).

Реклама создает образ мамы-волшебницы, способной решить любую проблему и справиться с любой задачей: «Моя мама - настоящая волшебница. Смотрите: она берет волшебный порошок - и происходит чудо! (мама быстро выводит грязь с футболки сына и нарисованная на футболке ракета выглядит ярче)... Новый Тайд для супермам...».

Мама является главным авторитетом для детей, ее мнение очень ценно.

Пример (из рекламного ролика косметики «Черный жемчуг»):

Дочь: - Мне очень важно, чтобы мою работу оценила мама (мама с дочерью смотрят запись телепередачи, где дочь - в роли телеведущей).

Мама: - Ну что ж, вполне достойно. Эмоционально, выразительно.

Дочь: - Изаметь, никаких мимических морщин.

На основании рекламных текстов можно сделать вывод о том, что в концепте мать содержится также элемент похожести, идентичности, общности интересов с ребенком: «Мы с мамой ужасно похожи. Она любит мои книжки. Она даже читает их вслух. А еще она любит футбол. И мой сок Ясли-сад. В общем, вкусы у нас одинаковые. Повезло мне с мамой. Ясли-сад: мама знает, чему я рад».

Именно поэтому в отношениях между матерью и ребенком царит полное взаимопонимание.

Ядро рекламного концепта отеи составляют такие центральные признаки, как любовь, забота, привязанность. В отличие от языкового концепта, рекламный концепт отец не включает в себя признаков отчужденности, дистанции или власти. Напротив, отношения с отцом можно охарактеризовать как дружеские, свободные и абсолютно непринужденные.

Подслот 2. Сын / дочь (кониепт сын актуализируется в 24 рекламных текстах, концепт дочь - в 16 рекламных текстах).

Примеры рекламных текстов подтверждают наблюдение о том, что воспитанию детей уделяется много энергии и сил. Однако сам процесс воспитания выглядит в рекламе достаточно упрощенно: чаще всего реклама демонстрирует «идеальных» детей, которые сами задают нужные вопросы, внимательно слушают родителей и полностью соглашаются с ними.

Пример (из рекламного ролика лекарства для горла «Лазалван»):

Сын спрашивает отиа: - А почему ты больше не кашляешь, Пап?

Отеи: - Я принимал «Лазалван» 
Сын: - Икак он помог?

Отец: - Представь, сынок, что это кашель царапает больное горло (для наглядности он проводит ножом по куску хлеба). А это «Лазалван» (намазывает хлеб медом). Он смазывает больное горло, а затем проникает глубоко в легкие и выводит мокроту..

Голос сына за кадром:

- Жить без кашля лучше вам - принимайте Лазалван.

В типичной ситуации ребенок вряд ли будет всерьез интересоваться воздействием лекарства на организм. Поэтому сама ситуация, когда сын с большим вниманием слушает рассказ отца и запоминает все, о чем он говорит, выглядит не очень естественно.

Подслот 3. Брат / сестра (актуализируется в 10 рекламных текстах)

Идея единения и поддержки, лежащая в основе данного подслота, широко используется в рекламе на телевидении, демонстрирующей, как брат с сестрой вместе изучают состав творога (реклама творога «Домик в деревне»), вместе пытаются пошутить над родителями, «превратив» дом в необитаемый остров (реклама мороженого «48 копеек»), совещаются, как убедить маму покупать им жевательную резинку каждый день (реклама Orbit). Взаимная поддержка и забота демонстрируются рекламой как основной вариант отношений между братом и сестрой: - Пап, смотри, что я брату нарисовала: он родится я ему подарю... (сок «Добрый»).

Негативные чувства по отношению к брату / сестре могут быть связаны с ощущением обиды на родителей за то, что кому-то из детей уделяется меньше внимания.

Терминал 2. Патриархальная семья

Образ патриархальной семьи представлен в 16 рекламных текстах.

Слот 1. Дом (актуализируется в 7 рекламных текстах)

Реклама часто обращается к «дому» как символу семейного уюта и спокойствия, где можно скрыться от ненастья и забыть о проблемах: «Лето закончилось, и впереди нас ждут дожди и морозы. Очень хочется, чтобы даже в ненастье у родных людей в доме были уют и тепло».

Атмосфера домашнего уюта имеет свой особый запах: запах вкусного обеда («...По квартире разносился приятный мясной аромат, и сразу же ожили воспоминания о зимних вечерах, когда мы собирались вместе...»), запах свежести («Гейт-микроспрей: аромат домашнего уюта»).

Концепт дом практически не актуализируется в рекламе в значении «крепость», «замкнутое пространство»: в рекламе хозяева дома всегда рады принимать гостей (семья зовет в гости своих соседей, чтобы вместе съесть торт «Причуда; сын приводит к себе на обед всю футбольную команду, и мама с удовольствием угощает их всех бульоном «Ролтон»).

Слот 2. Отдаленное родство (актуализируется в 16 рекламных текстах)

Подслот 1. Племянник / племянница (актуализируется в 2 рекламных текстах).

Реклама подтверждает мысль о том, что эта степень родства воспринимается как очень близкая. В рекламе стирального порошка «Персил» хозяйка рассказывает, как однажды к ней приехала погостить сестра «со своей шумной компанией». При этом племянники, находясь в гостях у тети, выглядят довольными и счастливыми: они бегают по дому и смеются, а тетя усаживает их рядом с собой на диван и крепко обнимает.

Подслот 2. Дядя / тетя (концепт дядя не представлен в рекламных текстах, концепт тетя актуализируется в 2-х рекламных текстах)

На основании собранных примеров можно сказать, что холодные,

XLinguae, Volume 10, Issue 4, October 2017, ISSN 1337-8384, eISSN 2453-711X 
сдержанные отношения с дядей / тетей, которые могут быть возможны в реальной жизни, совершенно не отражены в рекламе. Наоборот, реклама демонстрирует очень близкие и теплые отношения между тетей и племянником.

Подслот 4. Свекровь / свекор / теща / тесть (концепт свекровь актуализируется в 4-х рекламных текстах, кониепт тещча - в 3-х рекламных mекстаx)

Как правило, реклама открыто не демонстрирует враждебные чувства по отношению к свекрови. Хотя косвенно мысль о том, что между свекровью и невесткой редко может быть достигнуто полное взаимопонимание, находит свое выражение в рекламе. $B$ одном из рекламных роликов чистящего средства "Silit Bang» молодая хозяйка боится, что не успеет отчистить кухню от ржавчинь до приезда свекрови: «Свекровь уже едет!», но Silit помогает ей быстро справиться с уборкой, и хозяйка вздыхает с облегчением.

Гораздо чаще реклама демонстрирует мирные и даже теплые отношения со свекровью: невестка называет свекровь «мамой», просит у нее помощи и совета.

Подслот 5. Зять / сноха / невестка_(концепт зять актуализируется в 3-х рекламных текстах, кониеет невестка - в 4-х рекламных текстах)

Представление о том, что теща должна заботиться о зяте, ничего не жалеть для него, находит свое воплощение в рекламных текстах: «Щас тещ̧а приедет, пельменей налепит. А я их того, с майонезом. Пельмени - то русские, а Провансаль - Московский» (из рекламного ролика майонеза «Провансаль Московский»).

Образ «злой тещи» показан в рекламе чая «Принцесса Канди»: зять хочет зайти в комнату, попить чаю, а ему навстречу идет недовольная тещуа: «Ковер сто лет не выбивали, а он ходит чай пьет...». Зять не реагирует на ее замечание и молча уходит в другую комнату.

Представление о том, что невестка должна быть непременно глупа и неопытна, также находит свое воплощение в рекламе: «Почему Алла Ивановна доверяет свою кухню невестке? Потому что у нее есть АОС. Он отлично отмывает жир и сам легко смывается водой».

Подслот 6. Бабушка / дедушка (концепт бабушка актуализируется в 3-х рекламных текстах, концепт дедушка - в 1 рекламном тексте).

Образ доброй, заботливой бабушки широко используется в рекламе молочных продуктов «Домик в деревне». Бабушка - хранительница лучших семейных традиций и ценностей: только она знает, как правильно накормить внуков: - На вот тебе, горяченькие. Подожди, какие же блины без сметаны?

терминал 3. Родство по супружеству (актуализируется в 13 рекламных текстах)

Слот 1. Мужс / жена (актуализируется в 13 рекламных текстах)

Реклама в основном демонстрирует очень добрые и трепетные отношения между супругами, основанные на взаимной любви и заботе. Муж помогает жене приготовить обед и сам варит пельмени «Хозяйка дома», делает покупки для будущей мамы с помощью «Master Card», помогает ей ухаживать за малышом с помощью Фруто-няня. В свою очередь жена старается сделать все возможное, чтобы создать для своей семьи атмосферу домашнего тепла и счастья.

Реклама демонстрирует дружеские, теплые отношения между супругами, которые утратили былую романтику, но переросли в нечто большее: «Сколько супов я приготовила за эти годы... И все это ради него. Конечно, раньше мы были более страстными. Но теперь я не жду, что в доме каждый день будет пахнуть розами. Сейчас мне приятнее чувствовать аромат свежих овощей и трав. Ведь этот запах нравится моим мужчинам. Такова жизнь» (из 
рекламного ролика приправы «Кнорр»).

Слот 2. Брак (представлен в 2-х рекламных текстах)

Отношение к браку в рекламе довольно традиционное. Концепт брак актуализируется в рекламе в таких смыслах, как свадьба, любовь, «союз двух сердец». Именно поэтому невеста перед свадьбой выглядит счастливой и влюбленной: в рекламе зубной пасты Колгейт - свадебный танец. Муж восхищается красотой своей невесты, а невеста счастлива оттого, что «в самый счастливый день ее ульбка выглядит ослепительно».

Слот 3. Измена (актуализируется в 1 рекламном тексте)

Этот компонент концепта семья практически не представлен в рекламе, хотя можно привести один пример:

Муж приходит домой. На его лище - следы от губной помады.

- Дорогая, а ужин сково?

Жена держит в руках сковородку (собираясь ударить его ей):

- Сково, дорогой, сково...

Слоган: «Держи Сково»

Слот 4. Развод (актуализируется в 2-х рекламных текстах)

В последнее время разводы стали вполне обычным явлением, и это не могло не отразиться в рекламе.

Сопоставив языковую характеристику фреймовой модели концепта семья с фреймом, моделируемым на основе рекламных сообщений, мы обнаружили, что в целом структура фрейма семья, существующего в сознании носителей языка, совпадает со структурой данного фрейма, моделируемого на основе рекламных сообщений: в рекламном фрейме семья присутствуют те же терминалы, слоты и подслоты. При этом одни терминалы и слоты («родители / дети», «дом») представлены в рекламной коммуникации очень широко, в то время как другие (такие как «дядя / тетя», «свекровь / свекор / теща / тесть», «измена», «развод») встречаются лишь в единичных случаях. Анализ содержания самих слотов и подслотов показал, что образы свекрови, матери, дома и т.п., используемые в рекламе, не всегда соответствуют тем представлениям, которые существуют в сознании носителей языка. Скорее всего, это связано с желанием рекламистов воздействовать на адресата, вызвать у него нужные эмоции, ассоциации. Эксплуатируя образы «счастливых супругов», «идеальных родителей», «послушных детей», реклама делает для человека символически доступным то, о чем, возможно, он мечтает: отсутствие проблем с воспитанием детей, ссор, конфликтов, разногласий в семье и т.п.

На основании всего вышесказанного можно сделать вывод, что концепт семья представлен в рекламной коммуникации в достаточно искаженном виде.

\section{Концепт семья в дискурсе социальной рекламы}

Представим теперь модель концепта семья, реконструированного на основе сообщений социальной рекламы.

Терминал 1. Нуклеарная семья

Слот 1. Молодая семья (актуализируется в 3 текстах)

Новая ячейка общества - позитивный образ, состоящий из двух человек (мужчины и женщины), еще не имеющих детей. Ключевые компоненты данного слота - успех, будущее, любовь, счастье, выбор, уважение.

Пример 1. На плакате изображены руки мужчины и женщины, на безымянных - надеты кольиа. Слоган «Главное - гармония»: гармоничная, любямая пара, зарождение семьи.

Пример 2. Изображены ступени жизни. Картину сопровождает триада «Твой выбор. Твое решение. Твое будущее», где семья изображена на высшей ступени: создание семьи - это счастливое будущее, правильный путь.

\section{Слот 2. Материнство}

XLinguae, Volume 10, Issue 4, October 2017, ISSN 1337-8384, eISSN 2453-711X 
Подслот 1. Планирование и ожидание детей (актуализируется в 5 текстах)

Ключевые компоненты - ожидание, счастье, радость, любовь. Образ ответственные и любящие родители.

Пример. Благотворительным фондом защиты семьи, материнства и детства был создан плакат с лозунгом «Мы ТЕБЯ любим и ждем». Центральный символ - сердце из рук родителей, соединенных на животе беременной мамы.

Подслот 2. Мать (актуализируется в 11 текстах)

Ключевой образ - дающая жизнь, любящая мать. В этом случае ключевыми являются следующие компоненты: счастье, забота, энергия, радость, свечение, будущее.

Пример 1. Пожалуй, для женшины нет ничего прекраснее на свете, чем быть мамой. Так что, никакие растяжск с лишними килограммами не заменят этого счастья.

Пример 2. Что уж говорить, а беременная девуика - совершенство, ведь когда смотришь на будушую мамочку, складывается такое впечатление, будто она светится, изнутри излучая какую-то особую энергию.

Подслот 3. Мать-убийца (актуализируется в 6 текстах)

Представлен и отрицательный образ будущей матери, когда женщина идет на аборт, который в текстах социальной рекламы обычно характеризуется словами смерть, жестокость, детоубийство.

Пример 1. Аборт не аннулирует беременность. Он делает тебя матерью мертвого ребенка и оставляет отпечаток на всю жизнь!

Пример 2. Аборт - узаконенное детоубийство!

Слот 3. Отцивство

Подслот 1. Мужчина-защитник (актуализируется в 6 текстах)

Образ отца символизирует, прежде всего, главу семьи, ее защиту гордость. Мужчина - опора, пример для подражания.

Пример 1. У меня есть папа! Все равно, какой он! Лучший в мире папа, потому что мой он!

Пример 2. ... И я хочу лишь одного: пусть дольше сказка длится. Пока я с папой, ничего плохого не случится!

Помимо этого, в плакатах отражена тема важности отцовского воспитания: ключевые идеи - воспитание настоящего мужчины, счастье быть отцом, потребность в папе.

Пример. Настоящими мужчинами не рождаются - их воспитывают.

Подслот 2. Мужчина-должник (актуализируется в 4 текстах)

В качестве негативного выступает образ отца, бросившего семью, не платящего алименты или вынудившего женщину отказаться от ребенка. Реклама призывает отцов помнить, что у них есть семья и нужно не забывать о детях и своих родительских обязанностях. Ключевые понятия - должник, матьодиночка.

Пример 1. Бывиих детей не бывает, заплатите алименты!

Пример 2. Муж и отеи в семье должен быть, а не значиться.

Проблема абортов в современной России весьма актуальна. Сообщения социальной рекламы призывают мужчин взять ответственность на себя и не дать своей «второй половинке» сделать аборт.

Пример. Будь мужчиной! Возьми ответственность на себя! Спаси своего ребенка от аборта.

Слот 4. Полноценная семья (актуализируется в 18 текстах)

В России и в большинстве европейских стран многодетной считается семья, в которой трое или более детей. Тексты социальной рекламы формируют мнение, что полноценна семья, в которой два или три ребенка. Истинное 
счастье в детях, дети - будущее. Ключевые компоненты этого слота - счастье, радость, ответственность, поддержка. Образ - большая семья.

Пример 1. Семья бесиенна, когда полноченна. Когда в ней двое и более детей. Надели себя полноченным семейным счастьем!

Пример 2. Один ребенок - это счастье! Два - вдвойне! Планируйте не меньше трех! И будьте действительно счастливь!! текстах)

Терминал 2. Взаимоотношения в семье (актуализируется в 27

Терминал посвящен проблеме воспитания, вопросу семейных ценностей и отношениям поколений.

Слот 1. Отношение к представителям старшего поколения (актуализируется в 8 текстах)

Не менее важна в настоящее время тема любви к родителям, уважения к старшему поколению, в том числе к бабушкам/дедушкам. Ключевые компоненты - любовь, тепло, уважение, благодарность, с другой стороны одиночество, обида.

В большинстве текстов делается акцент на том, что дети должны любить своих родителей, заботиться о них.

Пример 1. Вырвавшись из родного «гнезда», одни дети заботливы, не забывают родителей, другие проявляют внимание по праздникам либо строго по расписанию, третьи упархивают, вспоминая об отчем доме зачастую очень поздно, когда навещать уже некого...

Пример 2. Пожилая женщина смотрит в окно; совсем недавно она связала плед, из нитей которого сложилось слово «одиночество». Вспомни, кто подарил тебе жизнь. Навести своих родителей.

Слот 2. Воспитание (актуализируется в 17 текстах)

Тексты социальной рекламы часто ориентированы на защиту детей: детей нужно любить и оберегать, неся за них ответственность. Ключевые компоненты слота - внимание, забота, любовь.

Подслот 1. Недостаток внимания по отночению к детям (актуализируется в 6 текстах)

Стереотипная ситуация для сообщений социальной рекламы: от недостатка внимания со стороны родителей дети могут погибнуть, стать жертвой дурного влияния. Взрослые - это пример для подражания. Ключевые компоненты подслота - ответственность, внимание, забота.

Пример. Говорят, что дети - иветы жизни. Чтобы вырастить в саду красивый иветок, человеку нужно приложить усилия, проявить заботу $u$ любовь. Также и родители во всех семьях должнь окружить свой маленький «иветок» заботой, лаской и любовью, чтобы в будущем из него вырос прекрасный и талантливый человек. Только нама любовь поможет вырасти нашим детям самыми красивыми иветками. текстах)

Подслот 2. Формирование семейных ценностей (актуализируется в 5

В вопросе о воспитании детей присутствует и тема правильных жизненных ориентиров, ценностей, которые каждый родитель должен привить своему ребенку.

Пример 1. Социальный ролик, обращающий внимание на семейные ценности, показывающий отношения как в одном поколении, так и между поколениями: «Казалось бы, это такие мелочи, но именно эти мелочи сохраняют теплую и нежную атмосферу в каждой семье. Ведь так приятно осознавать, что ты счастлив со своими родными и нужен им. Мы хотим, чтобы вы дорожили своими близкими и говорили искренние слова, когда они рядом».

XLinguae, Volume 10, Issue 4, October 2017, ISSN 1337-8384, eISSN 2453-711X 
Пример 2. Самые важные жизненные ценности - бесплатные. Семья является одной из них. Она очень важна в жизни каждого человека. Семья это самые близкие, родные люди, которых мы очень любим, которые дарят нам тепло и помогают в сложных ситуачиях. Это и родной дом, уютный $и$ безопасный. Поэтому важно, чтобы каждый понимал, что семья очень важна. Только они никогда не перестанут верить в тебя, поддержат в любой ситуачии.

\section{Терминал 3. Проблемы в семье}

Тематика данного терминала касается ряда базовых социальных проблем: насилия в семье, развода, различного рода зависимостей (курения, алкоголизма, наркомании) и заболеваний.

Слот 1. Развод (актуализируется в 3 текстах)

Развод - одна из наиболее распространенных тем современной социальной рекламы.

Пример. Плакат призывает молодежь более серьезно и ответственно принимать решения, которые изменят их жизнь, в частности - решение вступить в брак: «Начнись моя жизнь заново, я бы снова выбрала тебя. В России каждый 2-ой брак распадается. Выбирая, не спешите!» mекстах)

Слот 2. Пагубные привычки родителей (актуализируется в 13

Еще одна серьезная проблема, которой посвящены тексты социальной рекламы, - вредные привычки и зависимости родителей и - как следствие пагубное влияние на детей. Ключевые компоненты данного слота - стресс, проблема, зависимость.

Подслот 1. Курящая/пьющая мать (актуализируется в 4 текстах)

Bce рекламные сообщения данной тематики гиперболизированно негативны, чтобы произвести впечатление на массовое сознание, показав реальную угрозу здоровью детей. Образ курящей/пьющей матери отличается от образа курящего/пьющего отца: в большинстве случаев мать, страдающая пагубными привычками, изображается беременной (объяснимо тем, что она может нанести вред себе и своему будущему ребенку) либо в окружении детей дурной пример для подражания.

Пример. Каждый выпитый грамм алкоголя повреждает часть яйцеклеток, уменьшая вероятность рождения здоровых детей! Женские яйцеклетки не обновляются!

Подслот 2. Курящий/ пьющий отец (актуализируется в 9 текстах)

При разборе образа пьющего/курящего отца обратим внимание на частотную аналогию «Трезвый отец - счастливая семья». Делается упор на то, что отец несет ответственность за своих близких, как и мать, являясь примером.

Слот 3. Насилие в семье (актуализируется в 17 текстах)

Следующая анализируемая тема частично вытекает из предыдущей - это тема домашнего насилия в семье, а именно насилия над женщинами и детьми. Ключевые смысловые компоненты - жестокость, насилие, несправедливость.

Подслот 1. Насилие над женщинами

Сообщи об угрозе насилия, до того как станешь частью чей-то смерти. Свидетель домашнего насилия становится его соучастником.

\section{Подслот 2. Насилие над детьми}

Наряду с «домашним насилием» над женщиной, стоит вопрос жестокого обращения с детьми. Этот вопрос не менее актуален и все чаще затрагивается в текстах социальной рекламы, так как дети более уязвимы перед взрослыми и не могут постоять за себя.

Пример. Не бей! (визуальный компонент - плачущий ребенок)

Слот 4. Здоровье детей (актуализируется в 7 текстах) 
Кроме того, в текстах социальной рекламы большое внимание уделяется проблеме детей-инвалидов или детей, нуждающихся в дорогостоящем лечении. Зачастую детям с тяжелыми заболеваниями требуются дорогостоящие операции и лечение, и у родителей не всегда есть возможность самостоятельно решить эту проблему. Ключевые компоненты слота - выздоровление, надежда, помощь, шанс.

Увы, реабилитация и лечение далеко не бесплатны. Мама редко обращается за помощью к фонду, пытается справиться сама. Обычно у нее это получается. Но теперь финансовый ресурс семьи иссяк, а на новую программу по реабилитации Машеньки нужно собрать около 100 тысяч рублей. Помогите, пожалуйста, подарить Маше надежду на полноченную жизнь.

\section{Слот 5. Дети-сироты (актуализируется в 9 текстах)}

Сиротство - социальное явление, обусловленное наличием в обществе детей, оставшихся без родителей вследствие их смерти или лишения их родительских прав, признания родителей недееспособными, безвестно отсутствующими и т.д.

Данной проблеме посвящено множество текстов социальной рекламы, нацеленных на побуждение взять приемных детей в семью. Этот слот ориентирован на пробуждение в обществе чувств сострадания и милосердия, формирование представления о том, что приемный ребенок может стать таким же любимым и родным. семью).

Пример. Плакат «Чужих детей не бывает!» (ребенок-сирота рисует

Результаты, полученные в ходе исследования, подтвердили нашу гипотезу о том, что концепт семья, моделируемый на основании анализа текстов социальной рекламы, отличается от концепта семья, существующего в сознании носителей русского языка и представленного в текстах коммерческой рекламы, и эта трансформация осуществляется осознанно.

\section{Выводы}

Концептуальный анализ позволил нам прийти к следующим выводам.

1. В рекламном концепте семья присутствуют практически все терминалы и слоты языкового концепта семья.

2. Между семантическим содержанием концепта семья, реконструированного на основе текстов коммерческой и социальной рекламы, и концепта семья, существующего в сознании носителей языка, есть существенные отличия. Это связано с тем, что рекламные концепты имеют, помимо реальной, мифологическую сторону. Они оказывают на потребителя двойное воздействие как взятые на вооружение реалии социума и культуры и как мифологемы. Мифологическая сторона семья в социальной рекламе связана с понятиями любви, нежности, заботы, с одной стороны, и страха, стресса, боли - с другой, что является результатом отказа от предписанных социумом норм поведения. При этом в коммерческой рекламе превалируют положительные компоненты данного концепта.

3. Если сравнить основные компоненты концепта семья, существующего в сознании носителей языка и реконструированного на основе рекламных сообщений, можно обнаружить, что в составе концепта семья, представленного в социальной рекламе, преобладают негативные концептуальные признаки, такие как одиночество, страх, болезнь и т.п. В коммерческой же рекламе, напротив, на первый план выходят преимущественно положительные концептуальные компоненты, такие как крепость, любовь, близость, забота, совместный отдых. Анализ собранного материала показал также, что в «рекламном» концепте семья

XLinguae, Volume 10, Issue 4, October 2017, ISSN 1337-8384, eISSN 2453-711X 
присутствуют в основном эмоциональные компоненты (чувства между членами семьи, их привязанность друг к другу) и практически отсутствуют такие компоненты, как размер семьи, материальное положение и т.д. Такое избирательное обращение рекламистов к компонентам концепта семья можно объяснить особенностями рекламного текста: его прагматической направленностью, манипулятивным характером, задачей максимального воздействия на адресата.

4. В рекламной коммуникации образ нуклеарной семьи используется чаще, чем образ патриархальной семьи либо образ супружеской пары (без детей). Возможно, это связано с тем, что именно образ нуклеарной семьи является наиболее актуальным для современного российского сознания.

5. В коммуникации коммерческой рекламы слоты измена, развод представлены лишь в единичных случаях. Это говорит о том, что и рекламные тексты способны, скорее, укрепить традиционные представления о ценности, устойчивости, стабильности семьи, чем разрушить их. В социальной рекламе слот развод актуализируется достаточно часто, что обусловлено спецификой данного вида коммуникации, направленного на борьбу с разного рода социальными недугами.

\section{Bibliograpic references}

BIKTAGIROVA, Z.A. 2007. Koncept «sem'ya» v paremiologii anglijskogo, tureckogo i tatarskogo yazykov: avtoref. dis. ... kand. filol. nauk. Kazan'. 25 p.

CHISTYAKOVA, O.N. 2004. Koncept Sem'ya v povesti L. Ulickoj «Medeya i ee deti»// Russkaya i sopostavitel'naya filologiya: sostoyanie i perspektivy: trudy i materialy mezhdunarodnoj nauchnoj konferencii, posvyashchennoj 200-letiyu Kazanskogo universiteta 4-6 oktyabrya 2004 g. Kazan': Kazan. universitet. pp. 278279. ISBN: 5-98180-118-2.

DOBROVOL'SKAYA, E.V. 2005. Konceptualizaciya sem'i v russkoj yazykovoj kartine mira: avtoref. dis. ... kand. filol. nauk. Novosibirsk. 24 p.

KIREEVA, E.Z. 2008. Koncept «Sem'ya» v romane L.N. Tolstogo «Anna Karenina»: dis. ... kand. filol. nauk. Tula. 198 p.

MARCIN, J. 2011. Sitcoms: A Case for Stereotypes. In: XLinguae, European Scientific Language Journal, vol. 4, issue 2, 2011, pp. 26-30. ISSN 1337-8384.

MATVEEVA, M.V. 2007. Koncept «sem'ya» i ego reprezentaciya v russkom yazyke: dis. ... kand. filol. nauk. Tambov. 249 p.

OSIPOVA, A.A. - MIHINA, O.V. - POZDNYAKOVA, N.V. 2016. Reprezentatsiya kontseptov Rossiya i Germaniya $\mathrm{v}$ publitsisticheskih tekstah. In: Voprosyi kognitivnoy lingvistiki. № 3(48), s. 34-41. ISSN 1812-3228.

OZHEGOV, S.I. - SHVEDOVA, N.YU. 1995. Tolkovyj slovar' russkogo yazyka: 80000 slov i frazeologicheskih vyrazhenij. Moscow. 944 p. ISBN 978-5-9900358-6-7. ROZENFELD, J. 2011. Eastern European stereotypes in the British media. In: XLinguae, European Scientific Language Journal, vol. 4, issue 2, 2011, pp. 36-45. ISSN 1337-8384.

RUHLENKO, N.N. 2005. Koncept «sem'ya» v zhanre semejnyh rodoslovnyh: avtoref. dis. kand. filol. nauk. Belgorod. 22 p.

SHUlEZHKOVA, S.G. - MIHIN, A.N. - CHERNOVA, O.E. 2016. Kontseptyi revolyutsiya i voyna v materialah rossiyskih SMI ob Ukraine 2014-2015 gg. In: Voprosyi kognitivnoy lingvistiki. № 3(48), s. 50-61. ISSN 1812-3228.

SKAZKO, A.S. 2005. Transformaciya koncepta «sem'ya» v kul'ture Rossii: dis. kand. filol. nauk. Stavropol'. $171 \mathrm{p}$.

TERPAK, M.A. 2006. Anglijskij lingvokul'turnyj koncept «sem'ya» i sposoby otrazheniya ego konnotativnogo soderzhaniya v yazyke: na materiale semanticheskogo polya «Rodstvennye otnosheniya»: dis. kand. filol. nauk. Samara. 204 p. 
TIKHONOV, A.N. 1985. Slovoobrazovatel'nyj slovar' russkogo yazyka. V 2 t.: Ok. 145000 slov. T. 2. Moscow. 885 p. ISBN 5-200-01091-8.

Uchebnyj slovar' sochetaemosti slov russkogo yazyka / pod red. P.N. Denisova, V.V. Morkovkina. 1978. 688 p.

Исследование выполнено при финансовой поддержке РФФИ и Правительства Омской области в рамках научного проекта № 17-14-55001 «Региональный дискурс социальных коммуникаций: комплексный лингвокогнитивный анализ»

Words: 8106

Characters: 58956 (32,75 standard page)

Associate Prof. Marina Viktorovna Terskikh, PhD in Linguistics

Philology and Mediacommunication Department

Dostoevsky Omsk State University

55a Mira prospect

644077 Omsk

Russia

terskihm@mail.ru 